\title{
Причам ти историју: пројекат сторителинг радионица у сарадњи зрењанинског Музеја и Библиотеке
}

\author{
Тања Граовац \\ Градска народна библиотека „Жарко Зрењанин", Зрењанин \\ tanja.ciric@zrbiblio.rs
}

\section{Сажетак}

Рад представља пројекат реализован у сарадњи зрењанинског Музеја и Библиотеке, како би се превазишао проблем слабије заинтересованости младих за завичајно културно наслеђе. Уочен је и проблем недовољне отворености институција културе у комуникацији са новим генерацијама, који су учесници у пројекту покушали да реше употребом сторителинг технике учења и укључивањем различитих интерактивних, радионичарских елемената. Уз коришћење савремених технологија, водитељи радионица су покушали да локално наслеђе учине разумљивијим, ближим и атрактивнијим, као и да подстакну децу да самостално интерпретирају садржаје које нуде Библиотека и Музеј. У тексту су представљена теоријска разматрања о техникама сторителинга и сарадњи баштинских институција, да би се дао одговор

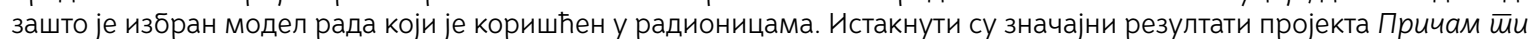
ист̄орију који се, по мишљењу ауторке, састоје у томе да су деца охрабрена да чешће и опуштеније долазе у Библиотеку и Музеј и да су заинтересована за локалну историју и подстакнута да даље истражују завичајно културно наслеће. При томе, успостављена је боља сарадња ове две институције културе.

Кључне речи: пројекат Причам ти историју, Градска народна библиотека „Жарко Зрењанин“, Народни музеј Зрењанин, баштинске установе, сторителинг (storytelling), завичајно наслеђе, радионице, едукација деце, савремени приступи локалном наслећу

\section{Увод}

Сврха овог рада је да се представи пројекат Причам иии истиорију: Storytelling у Музејy, peализован у сарадњи Народног музеја Зрењанин и Градске народне библиотеке „Жарко Зрењанин“. Он представља пример добре праксе сарадње две баштинске установе, успостављене како би се превазишао проблем недовољне заинтересованости млађе публике за завичајно културно наслеђе. Циљ пројекта био је да се, употребом сторителинг технике, деци основношколског узраста, на адекватан и занимљив начин, коришћењем нових приступа и технологија, представи локална културна баштина.

Сторителинг (storytellig) техника учења подразумевала је да се деци исприча прича, ауторска, оригинална, са развијеном фабулом и измишљеним ликовима, уз употребу реквизита, о одређеном историјском периоду, личности, грађевини или друштвеној појави. У причу су уткане чињенице из историје града. Кроз овакву употребу различитих наратива избегнуто је сувопарно предочавање чињеница, учесници су имали прилику да се емотивно ангажују, саосећајући са ликовима, или се поистовећујући са њима. Деци је остављен простор да постављају питања, говоре о својим запажањима, исказују своја осећања и мишљења, да погађају или предвиђају шта ће се догодити. Тако је превазиђен проблем пасивног учења о локалној историји и култури.

Изабрана је сарадња са музејом јер је сродан библиотеци по свом пореклу, мисији и изазовима са којима се данас суочава, али оно што је било пресудно за реализовану сарадњу јесте остваривање холистичког приступа представљању локалног културног наслеђа деци. 
Пројекат је трајао две године, током којих је реализовано 29 радионица и у којем су учествовали библиотекари, IT стручњаци, историчари уметности, археолози, етнолози, сликари, просветни радници, педагози и преко 700 деце.

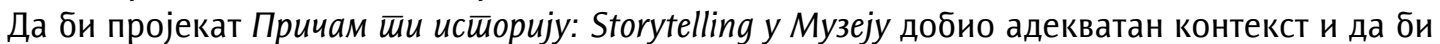
се боље разумео, неопходно је дати и теоријски оквир елемената који су били релевантни за његово реализовање. Зато се текст на почетку бави питањима како правилно укључити савремене технологије у рад културних институција (што је један од изазова када је у питању рад са младима у данашњим условима), да ли количина и већа доступност информација о прошлости у садашњем времену подразумева и пропорционалан раст знања и мудрости које она нуди, да ли се у баштинским институцијама данас практикује динамичан однос према традицији, зашто је интерсекторска сарадња, као и сарадња баштинских институција важна, шта је сторителинг и како се као техника користио у прошлости, а како од деведесетих година 20. века.

Задатак текста је да се заинтересованима олакша рад на спровођењу будућих, сличних пројеката, с обзиром да их досад, бар по сазнањима ауторке, код нас није било.

\section{Нови трендови и интерсекторска сарадња}

Развој информационо-комуникационе технологије утицао је на све сфере нашег бивствовања, па и на културу, доносећи нове трендове и изазове. Много тога доброг донеле су технологије, на првом месту доступност информација у доба знања. Постоје и проблеми, од којих би требало издвојити оне који доводе у питање да ли расположивост и број информација обезбеђују квалитетну информисаност и да ли доприносе квалитету живота, да ли доносе право знање, посебно кад је у питању бављење наслеђем. Нако велике, светске институције културе имају милионе прегледа на својим веб-страницама и на друштвеним мрежама, физичка посећеност остала је процентуално иста као и у прошлости, с обзиром на број становника, или чак мања. ${ }^{1}$ Упркос улагању великих напора да се дигитализује културно наслеђе, нажалост, веома мали број корисника, претежно стручњака, користи ову грађу. ${ }^{2}$ Томислав Шола каже да нисмо друштво знања, јер нисмо извукли поуке из прошлости, јер нам наслеђе није донело мудрост, ${ }^{3}$ а Нил Гејмен говори о нашем добу као о добу презасићености информацијама. ${ }^{4}$ Данијел Големан пише о социјалној усамљености у данашњем, никад бројнијем, друштву у којем „технологија нуди све више врста назовикомуникација, иако је, заправо, посреди изолованост“"која води у све веће одсуство емпатије. ${ }^{5}$

У таквој ситуацији, чини се, бар из угла теме овог рада, да је један од важних задатака институција културе данас да успостављају и негују управо емпатију, да постану места представљања традиције, места социјализације. Библиотеке и музеји требало би да децу (и одрасле) упућују и на развијање критичког мишљења, посебно кроз упознавање примера из прошлости, како би умела да разликују праве од лажних вести. И коначно, потребно је стално постављати питање о квалитету садржаја који се нуди кроз употребу савремене технологије у култури. ${ }^{6}$

\footnotetext{
1 О присутности музеја и галерија у виртуелном окружењу и резултатима које постижу пише у својој књизи Александра Савић, која се бави односима са јавношћу у београдском Природњачком музеју. - Aleksandra Savić, Muzeji u javnosti, javnost u muzejima (Beograd: Zavod za udžbenike, 2012).

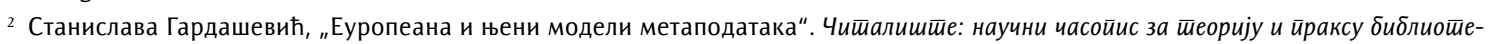
карсиива год. XII, бр. 22, 12 (2013): 85-93.

3 Томислав Шола врло разложно говори о овоме, између осталог, у свом интервјуу. - Tomislav Šola, „Na rubu znanosti-Mnemozofija“, video-zapis, objavljeno 26. 3. 2019, preuzeto 15. 12. 2019, https://www.youtube.com/watch?v=V19fj_up55o.

${ }^{4}$ Nil Gejmen, „Zašto naša budućnost zavisi од biblioteka, čitanja i maštarenja“, Buka, objavljeno 17. 12. 2017, preuzeto 10. 1. 2020, https://www.6yka.com/novosti/nil-gejmen-zasto-nasa-buducnost-zavisi-od-biblioteka-citanja-i-mastarenja.

${ }^{5}$ Danijel Goleman, Socijalna inteligencija (Beograd: Geopoetika, 2008), 15.

${ }^{6}$ Када се говори о квалитету садржаја, мисли се на квалитет програма у институцијама културе и на квалитет пројеката који се финансирају из буџета државе. Садржаји који су добро осмишљени и реализовани, лако се уклапају са корисном употребом савремене технологије, без бојазни да ће забава однети превагу над осталим компонентама неког пројекта.
} 
Граовац Т. „Причам ти историју: пројекат сторителинг радионица у сарадњи зрењанинског Музеја и Библиотеке“, 13-23

Када се ради о активностима које се баве културним наслеђем, требало би поћи од свеобухватнијег погледа на институције културе, који подразумева њихову сарадњу како би се досегла управо мудрост, практична употреба знања које баштини наша прошлост.

Темељне вредности библиотекарства данас се сагледавају кроз задатак чувања културне баштине, и то управо кроз сарадњу са другим баштинским установама. ${ }^{8}$ Постоје и примери који сведоче о томе да се криза читања успешно превазилази кроз реализацију интерсекторских пројеката. Говорећи о делатности краљевачке библиотеке у овој области сарадње, Милоје Радовић пише да је она уродила плодом и да се повећао број корисника услуга те библиотеке. ${ }^{9}$ И Градска народна библиотека „Жарко Зрењанин“ већ годинама уназад примењује интерсекторску сарадњу. Пројекат Storytelling у Музеју покренут је као логичан наставак таквог начина рада, заједно са Народним музејом Зрењанин, који, такође, има богату интерсекторску праксу.

\section{Додирне тачке библиотеке и музеја као основа баштинске сарадње}

Сарадња библиотеке и музеја логично произилази из њихове заједничке мисије, порекла, темеља и сличне финансијске ситуације. Повезују их задаци, однос према наслеђу, деле прилагођавање новим трендовима и младој публици. Ове институције сродне су и по свом производу ${ }^{10}$ и окренутости ка добробити заједнице. Деле и исту едукативну улогу у друштву. Њихова сарадња толико је природна, да се поставља питање зашто у Србији није системски више заступљена.

Једна од дефиниција, које, по мишљењу ауторке, најбоље одређује библиотеке и њихову мисију је она коју је написао Нил Гејмен: „Суштина библиотека је слобода. Слобода да се чита, слобода идеја, слобода комуникације. Њихова суштина је образовање (што није процес који се завршава оног дана када напустимо школу или факултет), забава, стварање безбедних места и приступ информацијама. (...) Ако не цените библиотеке онда не цените ни информацију ни културу ни мудрост. Угушујете гласове прошлости и штетите будућности". ${ }^{11}$ Иако говори о библиотекама, овакво становиште могло би се применити на све баштинске институције. Оно подразумева активнију улогу библиотека у односу са својим корисницима. Пишући о главним изазовима и циљевима који стоје пред музејима 21. века, Александра Савић наводи да музеји који отворе своја врата, и на томе остану, не комуницирају довољно са својим корисницима. Потребно је емотивно укључити посетиоца, онда ће се он осећати добро и осетити потребу да се у музеј врати. Ова институција би требало да има високоодговорну и активну улогу у својој заједници, да истражује потребе корисника, да прави програме по њиховој мери и укључи их у креирање својих активности. Такође, потребно је да музеји преузму нове улоге и моделе комуникације, посебно са младом публиком. ${ }^{12}$ С обзиром да је образовна улога у заједници на врху приоритета и музеја и библиотеке, заједничко им је и трагање за што ефикаснијим начинима привлачења публике новог доба и то најчешће кроз употребу нових технологија.

Динамичан однос према традицији такође је примаран за рад и библиотеке и музеја. Њихов задатак није само да чувају предмете који сведоче о богатству културног наслеђа једног

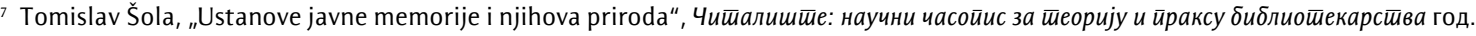
XII, бр. 22 (2013): 2-7.

8 Драгана Сабовљев, „Темељне вредности савременог библиотекарства“, Паниевачко иишалишие год. IX, бр. 16 (2010): 19-21.

${ }^{9}$ Miloje Radović, "Knjiga je ogledalo sveta. Model intersektorske saradnje u radu dečijeg odeljenja lokalne biblioteke". U Planeta čitalac: priručnik o razvoju publike u bibliotekama (Pančevo; Beograd: Gradska biblioteka Pančevo; udruženje Kulturis, 2014), 23-27, preuzeto 20. 2 2020, www.kulturis.org/projekti/planeta-citalac.

10 Овде се мисли на Шолино одређење производа баштинских установа које се налази у раду „Ustanove javne memorije i njihova priroda".

11 Gejmen, Nav. delo.

12 Savić, Nav. delo.
} 
народа, већ да их изнова представљају, постављајући их у контекст савременог човека. Томислав Шола говори и пише о томе да је задатак баштинских установа да, кроз интерпретацију знања које нуди наслеђе, подстичу кориснике да критички промишљају своју стварност, у реалном времену и са стварним људима. Баштина стварно постоји ако се у неком облику практикује, ако се кроз културно наслеђе афирмише и презентује нешто инспиративно, нешто добро, нека вештина из прошлости, ако се у њој проналазе подстицаји за садашњост. ${ }^{13}$ Производи музеја и библиотеке морали би се мерити доприносом општем добру заједница у којима делују. ${ }^{14}$

Установе културе налазе се и у сличној финансијској ситуацији. Све су мањи буџети које држава издваја за њих, па су приморане да се окрећу алтернативним изворима прихода. У таквим околностима, постоји ризик да садржаји који имају забаву као превасходни циљ, осиромаше и пројекте који интерпретирају културно наслеђе. На овај проблем упозорава и Дејвид Трозби: „Јавна политика мора да се чува претеране комерцијализације музејске делатности до које би могло да дође услед финансијских тешкоћа. Једна од највећих опасности је измештање мисије, када културне институције почињу превише да се ослањају на добит, тако да запоставе уметничке и образовне циљеве усмеравајући се на забавне понуде које обећавају далеко већу зараду“. ${ }^{15}$ Тако се поново долази до питања квалитета садржаја пројеката који се тичу интерпретације културног наслеђа.

\section{Сторителинг}

Да би се дефинисао појам сторителинга, требало би имати на уму чињеницу да је током времена овај појам добио ново значење. Причање приче је одувек практиковано - на техници усменог приповедања почивало је и целокупно народно стваралаштво. Иво Андрић, у свом чувеном есеју о причању, каже: „Тако нам понекад изгледа да човечанство од првог блеска свести, кроз векове прича само себи, у милион варијаната, упоредо са дахом својих плућа и ритмом свог била, стално исту причу“. ${ }^{16}$ Исто закључује и Кристијан Салмон, француски писац, у својој књизи ${ }^{17}$ о сторителингу, али се одмах потом пита да ли је то баш тако, да ли је данас то баш та добра, стара прича о којој говори и Андрић.

У данашње време, употреба сторителинг технике у корпорацијама, политици, маркетингу и војној индустрији толико се деформисала, да се претворила у машинерију за форматирање људских умова, у индустрију за производњу прича која злоупотребљава чак и Пропа, Фукоа и Барта. Салмон наводи податак да је 2007. године Google претраживач избацио преко 20 милиона резултата за појам storytelling, док данас иста претрага приказује 161 милион резултата. Занесеност овом техником у савремено доба је огромна и помало застрашујућа. Срећом, постоје и књиге, мада малобројне, које критички разматрају употребу технике причања прича. Још је мање литературе која озбиљно разматра њену употребу у култури, ваљда отуд што се она, у андрићевском смислу, заиста одувек користи. Салмон дефинише сторителинг технику која се данас користи у свим сегментима друштва и чини се врло прихватљивом: „Техника која се појавила средином деведесетих година прошлог века у Америци и заснива се на сторителингу (storytelling) или вештини приповедања прича. Од тада је ова техника, на све софистициранији начин, продрла свуда, у свет менаџмента, као и у свет политичке комуникације. Она подстиче на врло различите употребе наратива, од усменог приповедања, оног који користе

\footnotetext{
13 Šola, „Ustanove javne memorijei njihova priroda“.

14 Isto.

15 Dejvid Trozbi, Ekonomika kulturne politike (Beograd: Clio, 2012), 123.

${ }^{16}$ Ivo Andrić, "O priči i pričanju: Govor Ive Andrića u Stokholmu prilikom primanja Nobelove nagrade”, Писменица, оbjavljeno 23. 10. 2015, preuzeto 15. 3. 2020, https://www.pismenica.rs/knjizevnost/ivo-andric-o-prici-i-pricanju/.

17 Kristijan Salmon, Storytelling ili pričam ti priču: mašina za proizvodnju priča i formatiranje uma (Beograd: Clio, 2010).
} 
Граовац Т. „Причам ти историју: пројекат сторителинг радионица у сарадњи зрењанинског Музеја и Библиотеке“, 13-23

гриоти или приповедачи, па све до дигиталног сторителинга“. ${ }^{18}$ Свеопшта помама за сторителингом и вртоглаве цифре које се плаћају сторителинг гуруима удаљавају разумне људе од употребе овог појма, што је потребно нагласити, јер је током писања пројекта који је тема овог рада инсистирано на његовој употреби, баш због помињане занесености коришћењем овог израза данас, без јасног разграничења и дефинисања шта се под њим подразумева. Ауторка је мишљења да је правилнији појам приповедање, или причање приче, у смислу у којем га употребљава Андрић.

Сторителинг техника има многе предности. Она подразумева да се исприча прича, уместо да се користите класичне методе предавања путем предочавања чињеница о некој теми. У ту причу уплетене су чињенице, поуке, вештине или врлине које се желе пренети, али кроз авантуре које пролазе ликови приче, чиме је деци омогућено да се емотивно поистовећују и да, пратећи фабулу, лакше усвајају чињенице. Предности учења кроз приповедање у баштинским институцијама културе су бројне. Наравно, ако се правилно искористе и ако се води рачуна о квалитету приче и начину приповедања. Мисли се првенствено на Шолино одређење главног производа и предмета баштинских установа. Главне предности, због којих смо одабрали да пројекат реализујемо кроз употребу сторителинг технике јесу:

- За разлику од читања и писања, које су више индивидуалне активности, слушање прича са другом децом представља социјално искуство и развија емпатију код деце јер укључује дељење осећања и искустава са другима, развија и социјалну и емотивну интелигенцију. Приповедање се одвија у опуштеној атмсфери која позитивно утиче на процесе учења и памћења.

- Употребом сторителинг технике негују се имагинација и емотивна ангажованост, деца схватају да нису усамљена, да се неком раније дешавао исти процес, развијају креативност, критичко мишљење, способност предвиђања ситуација и могућих решења. ${ }^{19}$ Слушање прича, као и читање, развија способност исказивања сопствених мисли, развија језик, пружа знање о свету које омогућава вештине и алатке корисне за реалан свет. ${ }^{20}$

- У баштинским институцијама, причање прича пружа свеобухватнији, холистички приступ некој теми и одлична је допуна школским курикулумима

- Данашња деца много више знају о јунацима из холивудске/западне литературе него о ликовима из своје народне или митолошке традиције, што је сасвим разумљиво, с обзиром на велико присуство медија у њиховим животима. Такође, језик традиционалних форми деци није близак те зато имају потешкоћа да се са јунацима поистовете и да правилно разумеју поуке и вредности које пружа наслеђе. Отуд потреба да се новим генерацијама понуде нови, модерни начини представљања локалног и националног наслеђа, као и традиционалних усмених форми, за шта је сторителинг идеалан. ${ }^{21}$

\section{Причам йи истиорију: Storytelling у Музеју}

Storytelling у Музеју реализован је, под покровитељством Министарства културе и информисања Републике Србије, у два циклуса, током 2018. и 2019. године. Пројекат је остварен кроз сарадњу Градске народне библиотеке „Жарко Зрењанин“ и Народног музеја Зрењанин 22

\footnotetext{
18 Salmon, Nav. Delo.

${ }^{19}$ Mauro Dujmović, "Storytellig As a method of ELF Teaching", Metodički obzori: časopis za odgojno-obrazovnu teoriju i praksu vol. 1, no. 1 (2006): 75-78, preuzeto 22. 12. 2019, https://hrcak.srce.hr/11514.

20 Gejmen, Nav. delo.

${ }^{21}$ Nor Azan Mat Zin, Nur Yuhanis Mohd Nasir and Munirah Ghazali, "Promoting Socio-Cultural Values Through Storytelling Using Animation and Game Based Edutainment Software", preuzeto 20.12. 2019, https://www.researchgate.net/publication/267829766_ Promoting_Socio-Cultural_Values_Through_Storytelling_Using_Animation_and_Game-Based_Edutainment_Software.

22 Координаторке пројекта су Јелена Гвозденац Мартинов и Тања Граовац.
} 
и био је намењен деци основношколског узраста, али првенствено од 9 до 12 година. Број реализованих радионица био је већи од планираног јер је постојала велика заинтересованост за учешће у њима. Најпре је било предвиђено да се са децом уради 19 радионица, али их је изведено 29, јер је постојала жеља да се у активности укључе све основне школе у Зрењанину.

Библиотекари су, у договору са кустосима музеја, бирали теме за које су претпоставили да су најатрактивније за децу и које најбоље репрезентују локално културно наслеђе. Затим су библиотекар и кустос изучавали грађу везану за одабрану тематику и бирали литературу коју ће користити, али коју ће и представити и препоручити деци као смернице за њихова даља, самостална истраживања. Оно што је специфично за пројекат Storytelling у Музеју јесте да су библиотекари сами писали оригиналне приче које су приповедали деци. У приче су уткали чињенице о одабраном периоду, личности, грађевини итд., а затим их у музеју, окружени аутентичним експонатима везаним за тему прича, приповедали деци која су седела око њих. Седење у кругу око приповедача врло је битно јер утиче на стварање опуштене атмосфере. Деца имају утисак да су једнако важна колико и приповедач, самим тим су слободнија да износе своје мишљење и да учествују у разговору. Овако је превазиђен проблем извесног страха који деца понекад имају када слушају стручњаке у институцијама културе.

Приче су биле врло различите, у складу са разноврсним темама, али се испоставило да су све биле подједнако добре, судећи по реакцијама деце. Могу се груписати у неколико тематских блокова:

- Приче које су обрађивале предмете археолошке и природњачке збирке, одређене периоде (неолит, бронзано доба, камено доба, средњи век) - о лову у неолиту, о риболову у каменом добу, о мамутима и другим животињама у праисторији, о племенима која су насељавала Банат у првим вековима нове ере, о њиховим сукобима и културама, начину живота и обичајима;

- Приче о појединим грађевинама из историје града - о Бечкеречкој тврђави, о турском купатилу које је некад постојало у Зрењанину, о две зрењанинске цркве и свецима којима су посвећене;

- Приче са етнолошком темом и о традиционалним наративним формама: о девојачкој шкрињи, о бајци у српској традицији, о свадбеним обичајима и српској митологији, о зрењанинским сликаркама, о старим занатима у граду;

- Приче из новије историје, из Другог светског рата - о локалним херојима и хероинама овог периода, о партизанском покрету, о Ружи Шулман и Кочи Коларову, Жарку Зрењанину, о страдању Јевреја у Зрењанину;

- Приче о нашим завичајним писцима - о Тодору Манојловићу и Војиславу Деспотову;

- Приче о љубавним писмима кроз историју, од каменог доба до 21. века.

Из приказа тема види се да су обухваћени разни периоди локалне историје, као и различите области културе овог поднебља. Такође, на радионице су позивана деца која би у исто време у школама обрађивала тему која је одабрана.

Оно што је такође специфично за приче које су библиотекари писали и на чему је инсистирано, јесте да оне приказују свакодневни живот неког периода и да говоре о савременим проблемима деце и друштва. Испоставило се, након проучавања литературе о свакодневном животу одређеног периода, као и после разговора са музејским кустосима, да, и поред технолошког развоја, нема велике разлике у преокупацијама деце, оне из нпр. бронзаног доба и ове данашње. Страх је страх, игра је игра, љубимац је љубимац, љубав је љубав, пријатељство је одувек пријатељство, етикетирање и вршњачко насиље одувек постоје. Када се говорило о сликаркама и удаји, разговарало се и о родној равноправности, када су тема биле миграције у првим вековима нове ере, дискутовало се о толеранцији и мигрантима, а када је било речи о Бегеју и бићима која је Воја Деспотов населио око градске реке, причало се са децом и о еколошким темама. Након приче о Тодору Манојловићу, разговарало се о губитку вољених, о 
томе шта да се ради кад је неко тужан и да ли је туга саставни део живота, а кад се представљало турско купатило, причало се о развоју и значају хигијене кроз историју и о важности очувања природних ресурса данас. Инсистирало се на оваквом приступу имајући на уму оно што помиње и Шола, а то је да историја савремене људе није много научила и да из наслеђа не преузимају оно што би их учинило мудријима. Последњи пример, сада, у реалном времену, таквог поимања света налази се у часопису Storyteller, где епидемиолог Предраг Ђурић, пише: „Пандемије су у историји односиле велики број људских живота. Нажалост, често су биле праћене пандемијама стигматизације и дискриминације. Епидемија куге у Европи у средњем веку не само што је десетковала становништво већ је довела до погрома и прогона Јевреја из Западне Европе. Епидемија ХИВ инфекције такође је била праћена великом стигматизацијом. Чини се да нас историја није ничему научила."23

Током приповедања, користили су се многобројни реквизити. На пример, када се говорило о лову у неолиту, деци су донета крзна вука, лисице, зуби дивље свиње, мреже које се користе за лов на моруну итд. Реквизите су правили или доносили библиотекари и кустоси (српско платно, шкриње, лековито биље, везени и ткани предмети, папирне лутке - ликови из српске митологије, миришљаве купке, дрвени и картонски мачеви, шлемови, шешири, макете тврђаве или турског купатила, костур од старе новинске хартије, перле израђене по угледу на сарматски накит...). Припремане су и презентације за децу, којима је прича била илустрована и које су биле пројектоване на видео-биму иза приповедача. Кустоси су бирали из депоа музејског фонда експонате које би деца могла узети у руке и слободно их разгледати, а библиотекари су бирали кратке филмове који су такође пројектовани као илустрација прича. Припремајући се за радионице, библиотекари и кустоси су тако и сами много истраживали, читали и учили о завичају. Такође, током приповедања, остављано је времена за питања деце, за њихово мишљење и осећања, подстицана су да замишљају и погађају. Тако да је и само приповедање било интерактивно. Деци су припремани и разни поклони, од беџева, преко кромпир шећера, до ручно прављених купки, накита и украсних кутија, што их је посебно радовало.

Крај приповедања није био завршетак радионица. Уследио је, чини се, деци најзабавнији сегмент, када се од њих тражило да, кроз креативно изражавање, интерпретирају оно што су чула. На тај начин се могао стећи увид у то колико су усвојила и прихватила најзначајније поруке које прича о локалном наслеђу пружа. Библиотекари су користили ликовне, драмске, књижевне технике. Деца су цртала, вајала, правила моделе, глумила. На пример, када се говорило о археолошким локалитетима, учесници су у атријуму музеја, из песка, откопавали делове костура направљеног од папира декупаж техником и спајали га у целину. Цртали су у стилу експресионизма, јарким бојама, бића из српске митологије или створења из чудовиштаријума Воје Деспотова и словенске моноксиле. Правили су макете купатила из будућности. Писали су љубавна писма, на глиненим плочама, писаћим машинама, слагали су слова из штампарије.

У целу причу укључена је и употреба савремене технологије и савремених игара - изазова (challenge), деца су мобилним телефонима снимала кратке филмове у којима су глумила замишљени крај, сцену која би требло да прикаже како се завршава драма Тодора Манојловића Ценширифуїални иіраи. Играла су игру „Шта је у кутији“ (What's in the box), где је био робот из Star Wars саге, или су радила квиз у Kahoot апликацији. Гледала су филмове о томе колико могу лично да ураде на очувању природе, постовима на друштвеним мрежама. Чак ни тада није био крај радионице. Деца су добијала задатке који су подразумевали повратак у музеј или одлазак у библиотеку. Сви учесници су се поново сретали на изложбама радова у библиотеци, или су договаране пројекције филмова на тему двојника из песничког опуса Тодора Манојловића. Писали су бајке. Слали су фотографије на тему очувања природе.

23 PredragĐurić, „Pandemija koronavirusau uslovimavisoketehnologijeinesagledivih mogućnosti“ , Storyteller, intervju vodila Vladimíra Dorčová Valtnerová, 2. 4. 2020, preuzeto 10. 4. 2020, https://www.storyteller.rs/sr/pandemija-koronavirusa-u-uslovima-visoke -tehnologije-i-nesagledivih-mogucnosti/. 
Пошто је први пут реализован пројекат овако изазован и сложен, у којем је учествовало 12 библиотекара и 8 музеолога, постојале су многе недоумице. Али се брзо учило. Библиотекари су добили идеје за будуће активности. Реакције деце, родитеља, учитеља и наставника, као и других радника у култури и самих грађана, добра медијска пропраћеност радионица били су главни показатељи да је пројекат успео да заинтересује и децу и локалну заједницу за културну баштину.

\section{Резултати пројекта, проблеми и планови}

Само писање прича за библиотекаре, испоставило се, није представљало превелики проблем, посебно отуд што се током консултација на почетку пројекта разговарало о упутствима које о бајкама пружа књига Владимира Пропа. ${ }^{24}$ Одличан пример прича налази се и у књизи Ив Коа и Пјера Микела. ${ }^{25}$ Проблем библиотекара било је неискуство када је у питању само приповедање, или је боље рећи, непознавање глумачких техника. Они су били суочени са несигурношћу у изведби прича. Одлична упутства како се вежба за добру реализацију сторителига дао је Мауро Дујмовић. ${ }^{26}$ С обзиром на то да су библиотекари, припремајући се са кустосима и истражујући литературу о одабраној теми, и сами учили, и бивали изненађени колико недовољно знају о свом наслеђу, дешавало се да буду преопширни и имају проблем да сведу број релевантних чињеница које ће уврстити у причу. За то им је недостајало мало више педагошке припреме. Најједноставније речено, недостајала је претходна обука, водич, или семинар. Недовољна заинтересованост запослених у установама културе у којима су учесници пројекта радили такође није била мотивишућа. Потешкоћа у реализацији активности било је и због неприхватања нових трендова у баштинским институцијама о којима је било речи. Када се говори о доброј оспособљености кадрова запослених у институцијама културе, Владимир Кривошејев ${ }^{27}$ истиче неопходност „отварања“ баштинских установа за шири спектар других образовних профила, осим оних који су тренутно већински запослени у њима.

Једна од идеја је да се пренесе искуство стечено кроз реализацију Storytellinga у Музеју у виду неке форме водича, обуке за заинтересоване раднике у култури. Јавила се и идеја о објављивању збирке прича за децу о локалном наслеђу. Планови су и да се реализује трећи циклус радионица, али овога пута са децом из села општине Зрењанин. Осим деце и наставника, јављали су се и одрасли грађани, као и припадници трећег доба, вољни да учествују у пројекту, па се размишљало и о радионицама за те циљне групе. Постоји и идеја о даљој сарадњи, овога пута између све четири баштинске установе у Зрењанину (Историјског архива, Завода за заштиту споменика културе, Музеја и Библиотеке), како би се осмислила веб-страница о Тодору Манојловићу. Добра идеја је направити и игрицу или анимацију по традиционалним српским усменим формама, о митолошким јунацима или бићима. По узору на чланак о анимацији заснованој на традиционалним малезијским формама приповедања ${ }^{28}$ и на софтвер који користе, могла би се осмислити анимација по некој српској народној бајци или приповетки. Постоје реални проблеми када је у питању реализација ових планова у Србији. Не постоји асоцијација стручњака који раде у баштинским институцијама, попут удружења која постоје у региону или у свету, нити постоје утврђени приоритети и стратегије дигитализације националне баштине. ${ }^{29}$

\footnotetext{
24 Vladimir Prop, Morfologija bajke (Beograd: Prosveta, 1982).

${ }_{25}$ Iv Koa i Pjer Mikel, Antičke civilizacije: Egipćani, Drevna Grčka, Rimljani (Beograd: Mali princ, 2007).

26 Dujmović, „Storytellig As a method of ELF Teaching“.

27 Владимир Кривошејев, „Високо образовање стручних кадрова за рад у баштинским установама са посебним освртом на музе-

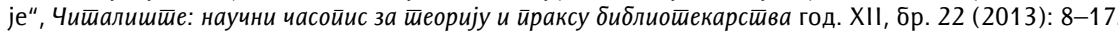

${ }_{28}$ Mat Zin, Nasir and Ghazali, "Promoting Socio-Cultural Values Through Storytelling Using Animation and Game Based Edutainment Software".

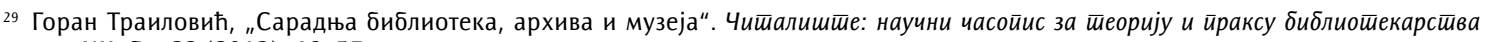
год. XII, бр. 22 (2013): 46-57.
} 
Граовац Т. „Причам ти историју: пројекат сторителинг радионица у сарадњи зрењанинског Музеја и Библиотеке“, 13-23

Резултати након спроведена два циклуса сторителинг радионица у музеју могу се сагледати кроз податке о томе колико је учињено за саму локалну заједницу, а огромно интересовање школа за радионице и реакције учесника су били мерило да се донесе закључак да је пројекат био успешан. Деца су своје утиске, самоиницијативно бележила у музејску књигу утисака, а била су охрабрена да буду сасвим искрена. Није било негативних коментара. Из интервјуа и анкета спроведених са децом, закључено је да је остварен план да се она трајније заинтересују за историју града и да им је метод учења кроз сторителинг технику донео бројне бенефите. ${ }^{30}$ Најчешћи одговори деце на питање шта разликује сторителинг радионице од оних које Библиотека или Музеј иначе реализују, били су: опуштена атмосфера и учење кроз причу. А то су два основна циља сторителинг радионица, да млађа публика осети удобност у институцијама културе и да се кроз форму приповедања пренесе знање о локалном културном наслеђу.

\section{Закључна разматрања}

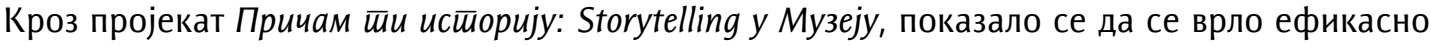
може остварити сарадња баштинских установа, кроз употребу савремених техника и технологија, како би се остварили заједнички циљеви и како би се придобила млађа публика. Пројекат овог типа био је велики изазов, али су из његове реализације „никле“ нове идеје и смернице за даљи рад. Оно што су библиотекари и музеолози знали и пре почетка пројекта јесте да им идеје, креативност и ентузијазам не недостају. Важан закључак је да успешно реализовани пројекти који третирају културно наслеђе морају бити део вишегодишње, добро осмишљене и конкретне, националне стратегије. Чак и кад појединачни пројекти уроде плодом, ма колико добри били, ако изостане континуитет квалитета, изостају и трајни ефекти за добробит локалне заједнице.

Радионице одржане у зрењанинском Музеју имале су превасходну сврху да едукују основношколце о локалном културном наслеђу, да их на забаван и опуштен начин упознају са радом институција културе, али и да их подстакну да сами даље истражују прошлост града. Током реализације активности, библиотекари и музеолози успоставили су одличну сарадњу, радећи са истим циљем, једни са другима, али и са децом која су учествовала у радионицама, као и са просветним радницима зрењанинских основних школа. Овакав вид сарадње допринео је обогаћивању и освежењу рада и школа и Музеја и Библиотеке.

Испоставило се да млади нису незаинтересовани за локалну баштину, већ би само требало пронаћи њима блиске начине комуникације, како би се превазишли проблеми недовољне посећености установа културе. Интенција да се млада публика заинтересује за садржаје које нуде зрењанински Музеј и Библиотека спроведена је кроз емотивно и социјално ангажоване наративе (сторителинг технику) и креативне интерпретације (радионичарски део пројекта, употреба савремене технологије) одабраних тема. Деци је успешно испричана прича о историји, завичају и завичајним великанима. Овакав закључак изведен је из чињенице да су се учесници пројекта радо враћали у установе културе, што даје наду да добро осмишљен пројекат може дати очекиване резултате.

\footnotetext{
30 По мишљењу ауторке, најилустративнији показатељ утицаја који је пројекат остварио на локалну заједницу, била су два догађаја, као две драгоцене повратне информације о раду на пројекту. Након што је урађена радионица о Воји Деспотову, деца која су учествовала у њој дошла су у библиотеку, тражила су књиге овог аутора које су годинама биле слабо издаване, према речима библотекарки са Дечјег одељења, а затим су о тим књигама писала за манифестацију Чишалачка значка. Дакле, заинтересована су за даље самостално бављење завичајним писцем. Други део радионице о племенима која су живела на тлу Баната на самом почетку нове ере предвиђао је да учесници кроз драмску игру одглуме велику размену добара три различита племена. Поента је била да направе сами замишљена добра, осмисле поздраве за своје племе, а затим да та добра и поздраве размене, како би научили да је међусобна сарадња паметнија од пљачки и сукоба са другима. Након ове радионице, чули смо од родитеља да су се деца играла ове игре и развијала је даље, у свом крају, међу блоковима својих зграда. Наставник историје који их је довео на радионицу на наредним часовима са њима је осмишљавао обележја и митове њихових племена. Тако смо децу истински заинтересовали за период праисторије који су обрађивала и у школи.
} 


\section{Литература и извори:}

1. Andrić, Ivo. „O priči i pričanju: Govor Ive Andrića u Stokholmu prilikom primanja Nobelove nagrade“. Pismenica. Objavljeno 23. 10. 2015, preuzeto 15. 3. 2020. https://www.pismenica.rs/knjizevnost/ ivo-andric-o-prici-i-pricanju/.

2. Dujmović, Mauro."Storytellig As a method of ELF Teaching". Metodički obzori: časopis za odgojno-obrazovnu teoriju i praksu vol. 1, no. 1 (2006): 75-78. Preuzeto 22. 12. 2019. https://hrcak.srce.hr/11514.

3. Đurić, Predrag. „Pandemija koronavirusa u uslovima visoke tehnologije i nesagledivih mogućnosti”. Storyteller. Intervju vodila Vladimíra Dorčová Valtnerová, 2. 4. 2020. Preuzeto 10. 4. 2020. https://www. storyteller.rs/sr/pandemija-koronavirusa-u-uslovima-visoke-tehnologije-i-nesagledivih-mogucnosti/.

4. Gardašević, Stanislava. „Europeana i njeni modeli metapodataka“. Čitalište: naučni časopis za teoriju i praksu bibliotekarstva god. XII, br. 22 (2013): 85-93.

5. Gejmen, Nil. „Zašto naša budućnost zavisi од biblioteka, čitanja i maštarenja“. Buka. Objavljeno 17. 12. 2017, preuzeto 10. 1. 2020. https://www.6yka.com/novosti/ nil-gejmen-zasto-nasa-buducnost-zavisi-od-biblioteka-citanja-i-mastarenja.

6. Goleman, Danijel. Socijalna inteligencija. Beograd: Geopoetika, 2008.

7. Koa, Iv i Pjer Mikel. Antičke civilizacije: Egipćani, Drevna Grčka, Rimljani. Beograd: Mali princ, 2007.

8. Krivošejev, Vladimir. „Visoko obrazovanje stručnih kadrova za rad u baštinskim ustanovama sa posebnim osvrtom na muzeje". Čitalište: naučni časopis za teoriju i praksu bibliotekarstva god. XII, br. 22 (2013): 8-17.

9. Mat Zin, Nor Azan, Nur Yuhanis Mohd Nasir and Munirah Ghazali. "Promoting Socio-Cultural Values Through Storytelling Using Animation and Game Based Edutainment Software". Preuzeto 20. 12. 2019. https://www.researchgate.net/publication/267829766_Promoting_Socio-Cultural_Values_Through_Storytelling_Using_Animation_and_Game-Based_Edutainment_Software.

10. Prop, Vladimir. Morfologija bajke. Beograd: Prosveta, 1982.

11. Radović, Miloje. „Knjiga je ogledalo sveta. Model intersektorske saradnje u radu dečijeg odeljenja lokalne biblioteke". U Planeta čitalac: priručnik o razvoju publike u bibliotekama, 23-27. Pančevo; Beograd: Gradska biblioteka Pančevo; udruženje Kulturis, 2014. Preuzeto 20. 2 2020. www.kulturis.org/projekti/ planeta-citalac.

12. Sabovljev, Dragana. „Temeljne vrednosti savremenog bibliotekarstva“. Pančevačko čitalište god. IX, br. 16 (2010): 19-21.

13. Salmon, Kristijan. Storytelling ili pričam ti priču: mašina za proizvodnju priča i formatiranje uma. Beograd: Clio, 2010.

14. Savić, Aleksandra. Muzeji u javnosti, javnost u muzejima. Beograd: Zavod za udžbenike, 2012.

15. Šola, Tomislav. „Na rubu znanosti-Mnemozofija“. Video-zapis. Objavljeno 26. 3. 2019, preuzeto 15. 12. 2019. https://www.youtube.com/watch?v=VI9fj_up55o.

16. Šola, Tomislav. „Ustanove javne memorije i njihova priroda“. Čitalište: naučni časopis za teoriju i praksu bibliotekarstva god. XII br. 22 (2013): 2-7.

17. Trailović, Goran. „Saradnja biblioteka, arhiva i muzeja“. Čitalište: naučni časopis za teoriju i praksu bibliotekarstva god. XII, br. 22 (2013): 46-57.

18. Trozbi, Dejvid. Ekonomika kulturne politike. Beograd: Clio, 2012. 


\title{
I Am Telling You a History: Storytelling Workshops Project - Cooperation between Museum and Library in Zrenjanin
}

\begin{abstract}
Summary
The paper presents a project implemented by the Museum and the Public Library in Zrenjanin, in order to overcome the problem of insufficient interest of young people in the homeland cultural heritage. The problem of insufficient openness of cultural institutions in communication with new generations was also noticed, which the participants in the project tried to solve by using storytelling learning techniques and by including various interactive, workshop elements. Using modern technologies, the workshops leaders tried to make the local heritage more understandable and attractive to the youth, as well as to encourage the children of primary school age to independently interpret the contents offered by the Library and the Museum. The work presents theoretical considerations on storytelling techniques and cooperation among heritage institutions, in order to give an answer as to why the model of work used in the workshops was chosen. Significant results of the project I Am Telling You a History were highlighted, which, in the author's opinion, consist in encouraging children to come to the Library and the Museum more often and more relaxed, in developing their interest in local history, and inspiring them to further explore local cultural heritage. Besides, better cooperation between these two cultural institutions has been established. The results after the two cycles of storytelling workshops in the museum can be seen through the data on how much has been done for the local community itself. Based on the great interest of schools to participate in the workshops and the reaction of participants, it can be concluded that the project was successful. An important conclusion is that successfully implemented projects that treat cultural heritage must be part of an enduring, well-designed and concrete national strategy. Individual projects can be very good, and achieve extremely good results, but if there is no continuity of quality, there are no lasting effects for the benefit of the local community. The aim of the text is to make it easier for interested professionals to work on the implementation of similar projects, given that we have not had them so far, at least according to the information available to the author.
\end{abstract}

Keywords: project I Am Telling You a History, City Public Library "Žarko Zrenjanin", National Museum of Zrenjanin, heritage institutions, storytelling, homeland heritage, workshops, education of children, modern approaches to local heritage

Примљено: 4. априла 2020.

Исправке рукописа: 28. априла 2020 Прихваћено за објављивање: 10. маја 2020. 


\section{(ब) $(\Theta \Theta \Theta$}

Причам ти историју: пројекат сторителинг радионица у сарадњи зрењанинског Музеја и Библиотеке ьу Тања Граовац is licensed under a Creative Commons Attribution-NonCommercial-NoDerivatives 4.0

International License. 